\title{
ERGOPOLIS: an ergonomics approach applied to a city.
}

\author{
Ricardo José Matos de Carvalho ${ }^{\mathrm{a},{ }^{, *}}$ \\ ${ }^{a}$ UFRN- Federal University of Rio Grande do Norte, Campus Universitário, Lagoa Nova, Technology Center, \\ Production Engineering Programme-PEP, Room 48, CEP: 59.072-970, Lagoa Nova, Natal, RN, Brazil. Tel/fax: \\ +55 (0xx84).3342.2403/9612.8180
}

\begin{abstract}
Ergopolis defines itself as an idea for thinking and transforming the city from the understanding of its own complexity and the complex human activity in it. The city is a living social organism where social production and reproduction take place. It is a sociotechnical and human-technological system where transformations and adaptations occur. The current article aims to gather and present cognitive ergonomics approaches, ranging from anthropotechnology, macroergonomics, resilience engineering and situated economy as a feasible theoretical and methodological path to be used in the understanding of the urban problems related to health, safety, accessibility, usability, mobility, people comfort and environmental sustainability of the city. The city is a situated space through which people with distinct features, capabilities and limitations perform daily singular activities i.e. leisure, entertainment or work notwithstanding whether they have economic and/or profitable aims or not.
\end{abstract}

Keywords: Ergopolis, ergonomics, cognition, resilience, city.

\section{Introduction}

The modern city has been producing problems that difficult the conduction and the promotion of people's lives, in terms of urban mobility, accessibility, safety and leisure, triggering to accidents, disasters and environment pollution.

"More than half of worldwide population live in cities" [1]. In 1900, 10\% of world population lived in urban centers, nowadays it is $50 \%$, e the prediction for 2050 is $75 \%$ [2]. In Brazil $84,35 \%$ of the people live in urban areas [3]. "The urban problem is no longer municipal, but national and global" [4].

Urban problems have different dimensions. The population density, the huge concentration of vehicles in the cities, the precariousness or inexistence of railway mass transport system (train and subway), the deficiency in road and traffic signage and problems on accessibility to pedestrians cause damages in urban mobility and traffic accidents, involving vehi- cles, heritage and pedestrians, making cities management more expensive.

According to the World Health Organization, in 2009 , around 1,3 million deaths were caused by traffic accidents in 178 countries. Brazil can be found in the fifth position among recordist countries in accidents rates, preceded by India, China, USA and Russia [5]. "According to the data available by the Ministry of Health, Brazil registers a rate of 18.9 fatalities in a group of 100 thousand inhabitants. Leader countries, some from Europe e others from Asia, register a rate of 5 deaths in a group of 100 thousand inhabitants"[6].

The accessibility issue is visible and with large coverage in the cities, due the existence of fisical and informational barriers, on the streets and public ways and built ambients, which make the orientation $\mathrm{e}$ locomotion hard to succed and cause accidents including pedestrians, mainly, those who have special conditions, such as blind people, elderly, obese and handicapped.

Ricardo José Matos de Carvalho, DSc. E-mail: rijmatos@gmail.com. Professor do Departamento de Engenharia de Produção DEP/UFRN. Programa de Pós-Graduação em Engenharia de Produção - PEP/UFRN. Grupo de Extensão e Pesquisa em Ergonomia GREPE/UFRN. 
The city has made some areas of science interested as architecture, sociology, geography, engineering etc. There is no studies with the purpose of assert the city and its systems as a potential space of research and application of ergonomics, considering its subsystems and aiming human activities done on those systems.

The ergonomics, historically, had kept its studies and interventions, first on military systems, then on industrial systems and recently, it has aimed the problems in service system, problems of accessibility in built ambients [7], problems in the traffic [8] of the cities and the problems related to craftsmanship [9], [10].

The approach presented by this article refers to introduce the city on the matters of ergonomics, without using the city as a sample of ergonomic studies. Human activities are taken as object of analysis, aiming the improvement of efficiency in the activities, health, safety and comfort of citizens. Therefore, it points to a possible to ergonomic analysis of human activities in the city as a method for researching and ergonomic action.

It is understood that the city is a site where the individual lives and in order to do that it is necessary to accomplish several production and use tasks, through a series of physical, cognitive and social interfaces in many locations: home, school, work, industry, commerce, services, squares, parks, theatre, cinema, football or sports stadium, laboratory, beach, hotel, hostel, airport, train station, bus station, subway, restaurant, street Market, public Market, supermarket, hospital, church, public ways, sidewalk, traffic, concert halls, etc.

The contemporary city has produced issues that make it difficult for people to lead their lives in terms of urban mobility and accessibility. It has also been the source of traffic jams, environmental pollution, accidents, disasters and catastrophes.

Such urban catastrophes generate crisis that paralyze the city, which is often unprepared to predict, prevent and manage them in a rational way thus generating failed random and improvised actions and regulations, as it sometimes happens with operational teams of emergency and help organisms on duty. Failures of such kind may aggravate the already chaotic flow of people and vehicles in the city affecting the high incidence of deaths, life quality degradation and high costs of city maintenance.

The problems of the city happen because of the hegemonic way the city itself is thought of and produced and also due to the government model chosen and executed - many times reactive (post-factum) instead of pro active (anticipation) - together with the values that municipal managers and organizations do have and disseminate into the people who live there thus being materialized in the options they make in terms of technology, facilities, equipment, public space organization, work functioning of the city and the environment.

Ergonomics is a domain of knowledge and practice convergence of a group of subjects which intercooperate aiming to help understand human activities at work therefore causing transformations.

The word Ergopolis [11] herein suggested refers to one way how ergonomics look at the human activities that happen in the city. In that sense, besides work activities, the idea of ergopolis lies upon other dimensions of human activities to happen in the city: leisure, entertainment, study, service use etc.

The aim of such an ergonomics project for the city is to facilitate the life of those who live in town in terms of safety, accessibility, usability, mobility and cognition, either in normal situations or in those moments of crisis or emergency, so that the impacts to production, economy and life in the city are the least possible ones. This very kind of project is inserted in and suggests an ethics for the city, which must underlie intervention actions from public, private and social organizations.

The projects and interventions in the city must take into consideration that the cognition of the city is socially distributed and that the knowledge of the structures and interfaces involves is fundamental. Under situations of crisis, for instance, resilience and robustness of a city is to be optimized in the way that the systems of governance involved are thought in a situated way and are capable of assuring the sharing of information and also promote cooperative actions among the individuals whenever necessary.

The idea is that projects designed for the city are developed based on the effectiveness criteria and in the commitment that both the people and the environment are taken into consideration in a harmonic way in order to provide human beings with a socially dignified life, which can only be made possible in a city enabled to allow those who live and relate in it to have a socially dignified life.

The aim of the approach developed in the current article is to facilitate and promote life of those who live in the city from a biocentric understanding.

The human activities in the city certainly demand an interdisciplinary approach on ergonomics in order to cope with their own issues. It is the challenge of 
ergonomics to understand the way through which the city and its sites and artifacts were created and have been working and also how during their interaction with people they influence their health, comfort and safety.

The term Ergopolis is used on this article to define its perspective of thinking and operate the domain of the city, trying to understand some issues that cause damages on the population, from the interdisciplinary approach of ergonomics, focusing human activities, with the goal of improve the comfort, safety, and people's life quality, through adequation of the city based on their characteristics, capacity and limitation.

\section{Which city?}

Along history, a lot of thoughts about cities were discussed, in the politics point of view, ethics, esthetics and its development, since ancient Greece (Plato), passing by modern and contemporary scholars, in the areas of geography, psychology, architecture, medicine etc. Some concepts of city are going to be presented here:

\section{- Super Machine City:}

Lewis Mumford "qualified the cities of super machine", understanding them "beyond the technical aspects" and taking in consideration "its economical, ecological, abstract dimension, even the "wishing machines" that inhabit our unconscious pulsions" [12].

\section{- Paranoid City:}

Coelho [1] refers to two types of cities: spectacular city and paranoid city. The spectacular cities are built to be known as global cities, due the fact become global references because they have the presence of transnational companies, concentrate the elite of arts and science and receive a great number of tourists [1]. The paranoid cities, on the other hand, are cities that deconstruct, they possess catastrophic views, which cause apprehension and insecurity and are filled and ruined by the action of burglars, drug dealers, and homeless people [1]. In fact, those cities coexist in only one, result of social inequality and their political, organizational and projectable choices.

- Ideal or perfect City

Based on the cave myth, [13] idealize the utopian city, The idea of Callipolis, in other words, beautiful city, perfect and ideal in Plato, is a model for an ideal city, different of the real city, where we live, which is an imperfect copy of imaginary city.

\section{- Sustainable City}

The concept of sustainability or sustainable development is in evidence since the document Our Common Future, released by UN - United Nations. According to that document, sustainable development is the "Type of development which is able to ensure the needs from present without compromising future generations assessing their own needs" [14]. Although, there is not a consensus about that concept, or its causes and forms to solve problems related to unsustainability, that document proposes, among other things, the need of coping the urban challenges by municipal governments and nations around the world. The concept of Sustainable City arises as a proposal of changing focus, until then centered in development sustainability, to a discussion centered in society sustainability.

\section{- Decent City}

The idea of Decent City or Worthy City once suggested is inspired in the idea and concept of decent work by International Labor Organization, which means "any productive occupation and accordingly paid, exercised in freedom, equality and safety conditions and capable to ensure dignity to people's lives. The labor must be safe and healthy, to be decent" [15]. Following that lead, we could think about a worthy city which, obviously, integrates the decent work, but with a bigger coverage, once in the city, the labor divides the occupation of human lives with leisure, entertainment, rest, habitation and education.

\section{- Solidary City}

The city must be included in the solidary purpose, by the state or the citizens. The politics and actions in essence, must be solidary, because its goal is, actually, to take care of common well being, reserving itself to provide the service to the group, protecting and promoting comfort and safe life for those who live in the city. The solidary city favors the construction of a decent responsible and sustainable city. When the solidarity, by the state and citizens, present in the society is fragile the city tends to degrade, causing damages to the people who interact with it.

Lefevbre [16] dwelled on the idea of right of the city, title of his important book. For Lefevbre the 
right to the city raises as an answer to assure the right to attend human needs and desires that, somehow, are included in the city lifestyle. The author refers to the necessary city science, having it as an object [16]. It is good to make sure here that there is not the intension to ascend ergonomics to a kind of city science. Therefore, it is suggested to bring the centrality of human activities to understand certain issues of the city, and using it to improve the way we think and transform the city since and for the citizens.

\section{The city and its issues}

"The cities had become blind, without group projects and it led to think of the city as an amount of fragments: instead of integral order, isolated thoughts were directed to potentially dynamic zones" [1].

The public systems responsible to the governance and to support the city have been faced with difficulties on how to act in certain situations, some of them more complex than others. It was realized the absence of integrated approaches and aimed to overpass some issues found in the city.

Most of the problems are related to the way of think and produce of the city, the governance that is linked with values, politics, instruments used and with form the managers treat and plan the city. The behavior of people or citizens are influenced by all those factors and appears in the relation with the city, as the usage of technology, installations, equipment, or as the occupation of public spaces considering the environment.

Urban cities suffer a considering population density and the historical absence of sustainable planning and proper projects to human activities, that situation is aggravated by the increasing progress of conurbation [17], responsible for the emergence of metropolitan areas, for the start of politic-managerial conflicts between the cities involved and for the social problems in the city.

Daily urban facts register long time and huge amount of fossil energy spent to people and property dislocate from one point in the city to another. The precarious urban mobility contributes to increase the environment pollution, the traffic accident risk, the inefficiency of mobile emergency services (such as police, firefight department etc) destined to the population, irritability of people, urban violence, diseases and the life and production cost in the cities.

The unplanned cities spread, a part driven by the unemployment and pauperization and other part dri- ven by the industrialization process in general, mainly, the progressive, excessive and irrational vertical trend of the edifications (as a result of the shocking presence of construction industry), have been causing problems as solo waterproofing, urban desertification, high rate of demographic occupation per built area, populational immigration to the suburbs, hills and river areas - forming slums - , pauperization and the extinction of local culture and economy, including problems in the systems of drainage, sewer, electricity and telephony.

The city, therefore, has become more vulnerable to natural disasters (storms, floods etc.), technological disasters (related to means of transportation, explosions, industrial accidents, industrial pollution etc) and social disasters (related to disorganized traffic flow, fire in urban and rural ecosystems).

Despite those problems, due the inexistence of a orderly and sustainable planning of occupation, there are physical accessibility problems (architectonical barriers) and informational problems (precarious space and traffic signaling) on the infrastructure public elements (public streets, routes, parking lots, stations, points for loading and unloading of passengers and loads, installation equipments), which difficult the urban mobility and accessibility to people.

The existence of information and physical barriers [7] situated on sidewalks, public ways, public streets and buildings, disclosure, most of times, that the projects for the built spaces/ambient in the city and the interventions have such a cognitive misery [18], because they do not take in consideration the real characteristics, capacity and limitations of users, not even the criteria of accessibility to users, generating hard orientation, loss of time, discomfort, risk of accidents and loss (human and material).

\section{Ergonomics and the city}

The city is understood as a site where individuals live and, in order to do that need to perform different activities of production and usage, work and rest, leisure and entertainment through a series of interfaces with physical, cognitive and social artifacts in several smaller sites: house, school, industry, commerce and services, squares, parks, theatres, cinemas, football stadiums, sports gym, lab, beach, hostels, hotels, airports, train station, bus station, subway, restaurant, street market, church, supermarket, public ways, traffic, sidewalks, roads, public market, concert halls and etc. 
The city is understood a human-technological system [19] or a social-technical system [20], with its technical and bio-psycho-social and cultural characteristics. It ranges from the understanding that the way through which the city, its sites and artifacts are conceived and organized do affect the health, comfort and security of people and their way of living in society both in the micro and macro social dimensions.

The city is understood as a situated space of social production and reproduction, of permanent humantechnological interface and also social, environmental and cultural interactions in contexts of normality and abnormality, such as: preparation and occasion of a world football cup or Olympic games, huge events in general, disasters ( traffic accidents, fires, explosions, storms, floods) etc.

Ergonomics presents itself as a convergence zone of knowledge and practices through subjects which cooperate in the sense of helping to understand human activities by an operating modeling of activities thus suggesting a descriptive memorial of such transformations [21].

Ergopolis is herein presented as a look at ergonomics for the human activities that happen in the city. In this sense, besides work activities, ergopolis is linked to other dimensions of human activities that happen in the city: leisure, study, entertainment, rest, etc.

The aim of the current approach is to facilitate and promote life of people in town from a biocentric understanding of the city.

\section{Public action in the city: an interdisciplinary or transdisciplinarian perspective as an approach and methodology}

The current article represents an attempt to gather in an interdisciplinary $[22,23,24]$ or transdisciplinary $[25,23,26,24]$, the theoretical-methodological approaches to ergonomics (ergonomia situada [21, 27, 28]; ergonomia cognitive [29, 30, 31, 32, 33, 19, $34)$, of anthropotechnology [27, 35], macroergonomics [20], economic theory of sites [36, 37] or situated economy and resilience engineering [38] to respond to specific problems of the city.

- Situated ergonomics

Situated ergonomics applied to city issues and the approach of ergonomic which aims to understand the problems of production and health related to human activities performed daily in the city. It is suggested the understanding of the incorporated acting [30] of people engaged in interactions among themselves and these very people relating to other elements of the social and technical system, focusing on the context in which the situations of human activities are socially constructed. It is based on the idea that perception and understand of reality is connected to the presence of the observer in real life situations and their contexts.

- Cognitive Ergonomics

For P. Falzon [18] cognitive health " is to be competent, i.e.: to acquire competences that may be employed with success, to progress. The ignorance, the approached knowledge and "in mosaique" may take to cognitive misery "'.

"Cognitive ergonomics has as its domains the group of mental activities of the subjects engaged in performing a task" [39]. Cognition relates to mental processes of people, such as observation, perception, attention, memory, thought, decision, language, communication, learning and thinking.

Cognitive Ergonomics aims to "project, develop and implant adequate devices in the social and technical systems so that the resulting system works in a safe and effective way" [34].

It starts from the understanding the way how the city, its sites and artifacts are conceived and organized and thus influences health, comfort, security and life quality of people and their way of life in society ( micro and macro) From the ergonomics point of view, the city is the result of the ways its systems are thought, designed, developed and implemented. In this sense, the city is a place of information, knowledge and circulating rules, a place of common cognition, socially constructed, distributed and shared [34, 40].

The city is a live social organism, an adaptative system and being such, it is a system capable of self feedback, promoting its own learning (adaptative system, self-learning, autopoietic), through the interaction among subjects (cooperative system) and the subjects with cognitive artifacts (systems of help) and is also capable of creating (potentially creative system) its solutions and possibilities.

The city is a dynamic of interconnections and interactions caused by people and mediated by physical, cognitive and social artifacts.

- Anthropotechnology

Anthropotechnology is defined as the "adapting of technology to the reality of the buying country" [41]. "It aims to study and solve the difficulties of geo- 
graphic, anthropological and economical origin" [41] in a process of transference of technology from an industrially developed country (PDI) to a country on the way to industrial development (PVDI). Anthropotechnology incorporates ergonomics and expresses itself in a bigger scale of action, specific for the transference of technology between countries.

At the moment the approach of anthropotechnology has broadened and gone beyond its original conception of the study of technology transference between countries, but aiming to understand how and which are the impacts of the knowledge transference actions, of know-how and technology inside the organizations, communities and groups and among organizations, communities, groups and individuals, either in the same city or in different cities in the same or different countries.

- Macroergonomics

"Conceptually, macroergonomics is a top-down approach of socio-technical systems for the design of work systems and also the application of a global system of work project for the project of humanwork, human-machine and human-software interfaces" [20]. "As a matter of fact, the process of macroergonomics design is descendent (top-down), ascendent (bottom-up) and radial (middle out)" [20].

For Hendrick and Kleiner [20], " macro ergonomics deals with analysis and the design of work systems". The word work as used by the author assumes a generic meaning "to refer to any kind of activity or human effort. The systems refer to socio-technical subjects".

Originally thought for business macro management, the approach of macro ergonomics also allows perceiving the city as a sociotechnical system. It incorporates micro ergonomics, which is focused on the level of the individual and the subsystem, expanding the general level of the system of work.

- Situated Economy

The economic theory of the sites evokes the notion of site, of homo situs and of symbolic site of belonging in the sense of acknowledging facts and behaviours that occur in a situation as being social and dynamic constructs which lead to permanent processes of adaptation and evolution [36]. The aim of this theory is to "combine culture, economy e ecology, with emphasis on the local scale and the diversity of economic practices because it is in this level that all the empirical richness of the organizations and economical systems appear" [36].

- Resilience Engineering
"A system should only be called 'resilient' when it is tuned in such a way that it can utilize its potential abilities, to the utmost extent and in a controlled manner, both in expected and unexpected situations" [42].

"One measure of resilience is therefore the ability to create foresight - to anticipate the changing shape of risk, before failure and harm occurs" [38].

"Resilience engineering is a paradigm for safety management that focuses on how to help people cope with complexity under pressure to achieve success" [38].

\section{What kind of projects for the city may be demanded by the approach of Ergopolis?}

a) Accessibility in places of high populational concentration; evaluation of accident risk and accessibility in schools, markets, shopping centers, bus stations, train stations, hospitals, airports, hotels, Long Permanence Institutions - LPI, football stadiums, sports gymnasiums, parks, squares, urban transport terminals etc.

b) Urban mobility in situations of normality and crisis: evaluation of traffic bottlenecks and redesigns, reorganizing routes and signals for vehicles and pedestrians.

c) Usability of products and informational systems

for urban, occupational, domestic and leisure usage.

d) Analysis and control of risks and accident prevention: industrial organizations, services and livestock; informal workers; self-employed workers; high-risk jobs; residential condominiums etc.

e) Analysis of cognitive tasks in situations of crisis : services of help and emergency in the city (SAMU, Fire Brigade, police, Civil Defense etc).

f) Mapping and analysis of critical spots of traffic accidents and running over.

g) Analysis and project of road signaling and directions.

h) Analysis of technology transference.

i) Analysis of human activities (professional and non-professional) affected by economic sectors (disorganized tourism, real state industry, industrial fishing, petrochemicals, agro industry, mining etc): craft fisherman, craftsmen in general, small shopkeepers, agricultors etc . 


\section{Conclusion}

This article sought to show how the approach of ergonomics can be enlarged for beyond the perspective of work position, work activity or the situation of industrial work and, therefore, can be used to understand the human activities held on the city and interface issues present among the municipal population (humans) and the technological system which they interact directly in city

The central idea was to present some theoretical and conceptual references and communicate how ergonomics in association with the references can contribute to understand and facilitate human activities in the city. Based on the presupposition that ergonomics has and important theoretical and methodological contribution for the project and engineering of the city, take in consideration the characteristics, capacity and limitations of people holding their frequent activities.

The city, facing its complexity, direct the people, however, to many ways for interdisciplinary and transdisciplinary performance, looking to improvements related to people activities.

Think of management systems in the city in terms of complexity, points to the comprehension of how important is to intensify the connections and the connectivity among people, and following the lead, between people and other elements from the system (including non-human elements) .

The aim of a project in ergonomics is to increase the connection and connectivity of the people in the city, allowing a solidary, decent, inclusive, pro active, more intelligent and creative city, for it is adaptive and self-learning.

Ergopolis is an approach, guide by ergonomics, with the primordial objective, improve technical and social cognition of the city aiming the increase of its resilience, extended as the systemic ability to, dynamically, deal with expected and unexpected situations, guaranteeing the efficiency and effectiveness of the systems involved, avoiding overloaded systems, facilitating and promoting safety, comfort and quality of life of people in the city.

\section{References}

[1] T. Coelho [org.], A cultura pela cidade. Ed. Iluminuras Ltda., São Paulo, 2008, p, 09.

[2] N. G. Canclini, Imaginários culturais da cidade: conhecimento/espetáculo/desconhecimento, in: A cultura pela cidade, T. Coelho, [org.], Ed. Iluminuras 1tda, São Paulo, 2008, p. 16
[3] IBGE,

2010

http://www.ibge.gov.br/home/presidencia/noticias/noticia_vis ualiza.php?id_noticia=1766, consulted in september 7, $20 \overline{1} 1$.

[4] H. Lefebvre, A revolução urbana, $3^{\mathrm{a}}$ reimpressão, Editora UFMG, Belo Horizonte, 2008.

[5] DENATRAN 2011 http://www.denatran.gov.br/decada transito.htm, consulted in september 07, 2011.

[6] DENATRAN 2011, http://www.denatran.gov.br/campanhas/semana/2011/snt2011. $\underline{\mathrm{htm}}$, consulted in september 07, 2011.

[7] A. de Moraes [Org.], Ergodesign do ambiente construído e habitado: Ambiente Urbano, Ambiente Público, Ambiente Laboral, iUsEr, Rio de Janeiro, 2004.

[8] Y. I Noy, W. Karwowski, Handbook of Human Factors in Litigation, CRC Press, Boca Raton, FL, 2005.

[9] M. C. W. Saldanha, Projeto Jangadeiros, PEP/UFRN, NatalRN, 2009.

[10] M. C. W. Saldanha, Projeto Rendeiras da Vila de Ponta Negra, PEP/UFRN, Natal-RN, 2009.

[11]R. J. M. de Carvalho, Projeto de Pesquisa "Ergopolis", PEP/UFRN, Natal, 2010.

[12]F. Guattari, Caosmose: um novo paradigma estético, Ed. 34, Rio de Janeiro, $5^{\mathrm{a}}$ reimpressão, 2008.

[13]Platão. A república (ou da justiça), Trad. Edson Bini, EDIPRO, Bauru, SP, 2006.

[14]CMMAD-Comissão Mundial sobre Meio Ambiente e Desenvolvimento. Nosso futuro comum, $2^{\mathrm{a}}$ edição, FGV, Rio de Janeiro, 1991.

[15]ILO, Decent Work, cit., p.15.

[16]H. Lefebvre, Direito à cidade, Centauro editora, São Paulo, $1^{\mathrm{a}}$ reimpressão, 2009.

[17]P. Virílio, O espaço crítico, Trad. Paulo Roberto Pires, Ed. 34, Rio de Janeiro, $4^{\mathrm{a}}$ reimpressão, 2008.

[18]P. Falzon, Les activités cognitives au travail, CNAM / MÉDIAS, Paris, 1996/1997.

[19]K. Vicente, Homens e máquinas: como a tecnologia pode revolucionar a vida cotidiana, Ediouro, Rio de Janeiro, 2005.

[20]H. Hendrick and B. M. kleiner, Macroergonomia, EVC, Rio de Janeiro, 2006, $175 \mathrm{p}$

[21]F. Guérin, A. Laville, F. Daniellou, J. Duraffourg and A. Kerguelen, Compreender o trabalho para transformá-lo: a prática da ergonomia, Edgard Blucher, São Paulo, 2001.

[22]B. Nicolescu, Fundamentos metodológicos do diálogo transcultural, in: E. A. Carvalho, T. Mendonça [Org.], Ensaios de complexidade 2, Sulino, Porto Alegre, 2003.

[23]H. Assmann, Reencantar a educação: rumo à sociedade aprendente, Ed. Vozes, Petrópolis, RJ, 1998.

[24]P. Weil,; U. Dámbrosio, R. Crema, Rumo à nova transdisciplinaridade: sistemas abertos de conhecimento, Summus, São Paulo, 2003.

[25]E. R. Ciurana, Complexidade: elementos para uma definição, in: E. A. Carvalho, T. Mendonça [Org.], Ensaios de complexidade 2, Sulino, Porto Alegre, 2003.

[26]H. Simon, entrevista concedida, "L'ordinateur libere de ses maitres", Le Monde, april 10, 1984, in:G. Pessis-Pasternak, UNESP, São Paulo, $3^{\mathrm{a}}$ reimpressão, 1993.

[27]A. Wisner, Por dentro do trabalho: ergonomia método e técnica, FTD/Oboré, São Paulo, 1987.

[28] M. C. R. Vidal, Guia para Análise Ergonômica do Trabalho na empresa: uma metodologia realista, ordenada e sistemática, Virtual Científica, Rio de Janeiro, 2003.

[29] P. Falzon [Editor], Ergonomia, Edgard Blucher, São Paulo, 2007. 
[30] F. J. Varela, E. Thompson, E. Rosch, A mente incorporada: ciências cognitivas e experiência humana, Artmed,Porto Alegre, 2003.

[31] J. Reason, Human Error, Cambridge University Press, NY, 1999.

[32] K. J. Vicente and J. Rasmussen, Ecological Interface Design Theoretical foundations, IEEE Transactions on Systems, Man and Cybernetics (22) (589-606), 1992.

[33] C. E. Zsambok and G. Klein [Editors], Naturalistic Decision Making, LEA, New Jersey/EUA, 1997

[34] M. C. R. Vidal and P. V. R. de Carvalho, Ergonomia Cognitiva: raciocínio e decisão no trabalho, EVC, Rio de Janeiro, 2008.

[35] A. Wisner, Antropotecnologia: ferramenta ou engodo, in: Textos escolhidos: antropotecnologia, EVC, Rio de Janeiro, 2004.

[36] H. Zaoual, Nova economia das iniciativas locais: uma introdução ao pensamento pós-global, DP\&A Editora, Rio de Janeiro, 2006

[37] H. Panhuys, Do desenvolvimento global aos sítios locais: uma crítica metodológica à globalização, E-papers, Rio de Janeiro, 2006

[38] E. Hollnagel, and D. D. Woods, Prologue: resilience engineering concepts, in: E. Hollnagel, D. D. Woods and N. Leveson, Resilience Engineering: concepts and precepts, ASHGATE, England, 2008.

[39] P. Falzon, Ergonomie cognitive Du dialogue, Presses Universitaires de Grenoble, Grenoble, 1989.

[40] F. Decortis and B. Pavard, Communication et cooperation: de la théorie des actes de langage à l'approche ethnométhodologique, in: B. Pavard [Dir.], Systèmes coopératifs: de La modélisation à La conception, Octares Ed., Toulouse, France, 1994.

[41] A. Wisner, A inteligência no trabalho: textos selecionados de ergonomia, Fundacentro, São Paulo, 1994.

[42] Y. Fujita, Resilient systems, in: E. Hollnagel, D. D. Woods, and N. Leveson, Resilience Engineering: concepts and precepts, ASHGATE, England, 2008. 